\author{
BARBARA Osóch \\ Uniwersytet Szczeciński, Polska - University of Szczecin, Poland \\ PaWet CZAPLIŃSKI \\ Uniwersytet Szczeciński, Polska - University of Szczecin, Poland
}

\title{
Państwowość jako determinanta intencji przedsiębiorczych młodzieży licealnej uczącej się w międzynarodowej grupie rówieśniczej (na przykładzie Szczecin International School)
}

\author{
Statehood as a Determinant of Entrepreneurial Intentions \\ of High School Youth (Case Study of Szczecin International School, Poland)
}

Streszczenie: Przyjęto, że normy społeczne i kody kulturowe obowiązujące w różnych społeczeństwach nie muszą determinować cech osobowościowych ucznia i sposobu jego myślenia niezależnie od aktualnego miejsca zamieszkania. W świetle powyższych ustaleń celem opracowania stała się analiza intencji przedsiębiorczych młodzieży licealnej mającej różne obywatelstwo. Głównym narzędziem pomiarowym była ankieta skierowana do uczniów Liceum Ogólnokształcącego działającego w Zespole Szkół Szczecin International School oraz Technikum Zawodowego przy Zespole Szkół Budowlanych, która stanowiła próbę porównawczą. Ankietę przeprowadzono w formie przekrojowego badania bezpośredniego, w okresie od kwietnia do maja $2018 \mathrm{r}$. Jak wynika z badania, istnieją różnice w charakterystyce intencji przedsiębiorczych młodych Polaków i obcokrajowców. Często silny bodziec o charakterze finansowym prowokuje polskich uczniów do szybszej, bardziej zdeterminowanej, chociaż czasem powierzchownie podjętej deklaracji gotowości do określonych zachowań przedsiębiorczych. W przypadku uczniów zagranicznych bodziec ten ma zdecydowanie mniejsze znaczenie, a zgłaszane intencje przedsiębiorcze wydają się być bardziej przemyślane.

\begin{abstract}
It has been assumed that social norms and cultural codes binding in different societies do not have to determine the student's personality traits and the way of thinking regardless of the place where they live. Due to the above-mentioned issues the aim of the study was to analyse the entrepreneurial intentions of high school youth with different citizenship. The main measurement tool was a survey addressed to students of the high school in the School Complex of Szczecin International School and a Technical School of Construction named after Kazimierz Wielki, which was a comparative test. The questionnaire was conducted in the form of a cross-sectional study, from April to May 2018. As results from the conducted research, there are differences in the characteristics of entrepreneurial intentions of young Poles and foreigners. A strong financial stimulus provokes Polish students to a faster, more determined, although sometimes superficially made, declaration of readiness for specific entrepreneurial behaviours. In the case of foreign students, this stimulus is definitely less important, and the entrepreneurial intentions reported seem to be more thought-out.
\end{abstract}


Słowa kluczowe: intencje przedsiębiorcze; młodzież licealna; państwowość

Key words: entrepreneurial intentions; high school youth; statehood

Otrzymano: 25 października 2018

Received: 25 October 2018

Zaakceptowano: 27 lutego 2019

Accepted: 27 February 2019

Sugerowana cytacja/Suggested citation:

Osóch, B., Czapliński, P. (2019). Państwowość jako determinanta intencji przedsiębiorczych młodzieży licealnej uczącej się w międzynarodowej grupie rówieśniczej (na przykładzie Szczecin International School). Przedsiębiorczość - Edukacja [Entrepreneurship - Education], 15(1), 61-74. doi: $10.24917 / 20833296.151 .5$

\section{Wstęp}

Jedną z najbardziej znanych i empirycznie zweryfikowanych konstrukcji teoretycznych, do których odwołuje się wielu autorów próbujących wyjaśnić intencje przedsiębiorcze, jest stworzona przez Ajzena $(1985,1991)$ teoria planowanego zachowania ${ }^{1}$ (zob. Ambad, Damit, 2016; Krueger, Reilly, Carsrud, 2000; Kurczewska, 2010, 2013; Okręglicka i in., 2017; Pawlak, 2015; Rachwał, Wach, 2016; Schlaegel, Koenig, 2014; Thompson, 2009 i wielu innych). Zakłada ona, że podstawowym czynnikiem wyjaśniającym zachowania jest indywidualna intencja związana $z$ wykonaniem określonej czynności. Natomiast sama intencja rozumiana jako: „własne przekonanie o zamierzeniu stworzenia przedsięwzięcia gospodarczego i świadomym planowaniu tego procesu w przyszłości" (Zbierowski, 2014), rodzi się w wyniku jednoczesnego działania pozostających ze sobą w określonych relacjach trzech czynników: nastawienia (postawy), możliwości (wykonalności) oraz norm społecznych, które stanowią podstawę i granicę możliwości kontrolowania własnej skuteczności (Wach, 2015). Interesujące jest również to, że na wspomniane trzy czynniki działa szereg zmiennych zewnętrznych natury demograficznej (np. wiek, płeć), społeczno-kulturowej (np. religia, kultura, narodowość, doświadczenia, relacje międzyludzkie), ekonomicznej (np. zamożność) oraz psychologicznej (np. osobowość, nastrój, emocje) (Fishbein, Ajzen, 2010).

Według A. Kurczewskiej (2010), zmienne zewnętrzne mają bardzo zróżnicowany charakter. Mogą wywodzić się z przesłanek biologicznych, w świetle których zachowanie człowieka wynika z jego osobowości, a ta nie ulega większym zmianom od urodzenia aż do śmierci. Stąd teza, że ludzie rodzą się z określonym zasobem przedsiębiorczości, a ten zostanie odkryty i wykorzystany lub nie. W innym podejściu, kognitywnym, które zakłada indywidualizm przedsiębiorcy, podkreśla się zdolność jednostki do łączenia różnego rodzaju niepowiązanych ze sobą informacji w celu identyfikacji albo stworzenia nowego produktu lub usługi oraz zgromadzenia potrzebnych zasobów, by rozpocząć lub rozwijać działalność gospodarczą. Z punktu widzenia podjętych badań szczególnie ważnym wydaje się być podejście kulturalistyczne oparte na założeniu, że otoczenie, w którym funkcjonuje człowiek, determinuje jego cechy osobowościowe i sposób myślenia. To z jego

\footnotetext{
${ }^{1}$ Teoria planowanego zachowania powstała w latach 80. XX w. na podstawie wcześniejszych założeń teorii przemyślanych działań (Fishbein, Ajzen, 1975)
} 
przekształcenia przyjęto tezę, że normy społeczne i kody kulturowe obowiązujące w różnych społeczeństwach nie muszą determinować cech osobowościowych ucznia i sposobów jego myślenia, w tym myślenia przedsiębiorczego.

W nawiązaniu do powyższych przesłanek szczególnej uwadze poddano termin „państwowość" rozumiany sensu stricto jako zespół cech właściwych państwu (Doroszewski, 1996). W szerszym znaczeniu można go rozumieć jako środowisko, czyli złożony i wzajemnie powiązany system, który tworzy krajowy kontekst działania w wymiarze przyrodniczym, społeczno-gospodarczym i kulturowym. Oddziałuje on bezpośrednio lub pośrednio na jednostkę, tworząc warunki brzegowe zachęcające (lub zniechęcające) m.in. do aktywności gospodarczej. Może się on również przyczyniać się do powstawania intencji przedsiębiorczych, w tym intencji przedsiębiorczych młodzieży, która jeśli przyjmie aktywną postawę rynkową i dostrzeże możliwości założenia własnego biznesu, skutecznie doprowadzi do jego uruchomienia w konkretnym miejscu, konkretnym państwie (Czapliński, Vepryk, 2008; Czapliński, Kibych, 2017).

Celem pracy była próba weryfikacji roli i znaczenia państwowości jako zmiennej zewnętrznej, która może wpływać nie tylko na sposób myślenia czy zachowania, ale również na kluczowe motywy działania uczniów pochodzących z różnych krajów w zakresie intencji przedsiębiorczych. Podjęty cel szczegółowy wpisuje się również w weryfikację znacznie szerszej tezy o wpływie środowiska (otoczenia) na funkcjonowanie jednostki (tu: ucznia), zwłaszcza na jego cechy osobowościowe i sposób myślenia, pierwotnie formowany w odmiennych od polskich, rodzinnych więziach kulturowych. Wreszcie, wyniki przeprowadzonych badań stanowią drobną przesłankę do dyskusji nad modelem zaproponowanym przez Ajzena (1985, 1991 i in.) w części poświęconej wpływom czynników zewnętrznych na tzw. antecedencje intencji zachowania, a pośrednio na intencje i zachowania przedsiębiorcze.

Do tak postawionego celu przypisano następującą hipotezę badawczą: normy społeczne i kody kulturowe obowiązujące w różnych społeczeństwach nie muszą determinować cech osobowościowych ucznia i sposobu jego myślenia.

\section{Założenia metodyczne badań}

Jako główne narzędzie badawcze zastosowano ankietyzację przeprowadzoną wśród uczniów Liceum Ogólnokształcącego w Zespole Szkół Szczecin International School oraz wśród grupy uczniów Technikum Zawodowego w Zespole Szkół Budowlanych im. Kazimierza Wielkiego w Szczecinie. Zdefiniowanie respondentów jako uczniów szkół średnich zapewnia spełnienie dwóch istotnych warunków metodycznych. Po pierwsze, pozwala na weryfikację intencji przedsiębiorczych wśród osób, które nie mają jeszcze możliwości podjęcia jakichkolwiek działań w tym zakresie. Po drugie, umożliwia uzyskanie realnego odzwierciedlenia analizowanego zjawiska wśród różnych grup społeczno-zawodowych.

Wybór miejsca badań na poziomie kraju miał charakter doboru celowego. Wybór Polski wynikał z dużej dynamiki jej rozwoju tak pod względem ducha przedsiębiorczości, jak i pod względem konkretnych działań (zob. Chaber i in., 2018; Global Entrepreneurship Monitor, 2018). Dobór Szczecina miał charakter doboru wygodnego (convenience sampling), niemniej Szczecin jako duże miasto portowe, położone peryferyjnie w strefie przygranicznej, o zróżnicowanej historycznie i kulturowo społeczności, miał zapewnić szeroką ofertę zdarzeń przedsiębiorczych oraz ewentualną ich internacjonalizację, 
co byłoby impulsem dla aktywności młodzieży licealnej. W celu zrealizowania postawionego celu na poziomie szkoły poszukiwano takiej placówki edukacyjnej średniego szczebla, której społeczność miałaby międzynarodowy charakter. Ostatecznie warunek ten został spełniony przez Szczecin International School (SIS).

Głównym narzędziem pomiarowym była ankieta skierowana do uczniów. Ankietowanie przeprowadzano $\mathrm{w}$ formie przekrojowego badania bezpośredniego, w okresie od kwietnia do maja 2018 r. Badaniem empirycznym objęto wszystkich uczniów SIS, tj. 47 osób. W skład tej grupy wchodzili Polacy (18 osób) i obcokrajowcy (29 osób), wśród których byli uczniowie z Niemiec, Danii, Litwy i Estonii. Grupę porównawczą stanowili uczniowie Technikum Zawodowego w Zespole Szkół Budowlanych (ZSB). Całkowicie polska grupa porównawcza liczyła łącznie 38 respondentów. Obie grupy razem, czyli 85 uczniów, to aktualnie mieszkańcy Szczecina lub jego strefy podmiejskiej. Zdecydowana większość badanych to mężczyźni (73\%).

Badanie przeprowadzono za pomocą ankiety sporządzonej w dwóch wersjach językowych. Dla SIS była to ankieta w języku angielskim, dla ZSB - w języku polskim. Kwestionariusz składał się z 11 pytań stanowiących zasadniczą część ankiety oraz 4 pytań zawartych w metryczce (pytania o narodowość, płeć, wiek, miejsce zamieszkania). Większość, tj. 13 pytań, miała charakter kafeterii dysjunktywnej lub koniunktywnej. Wybrany typ pytań miał ograniczyć ewentualne problemy językowe, sprzyjać jednoznaczności odpowiedzi oraz ułatwić procedurę kodowania ankiet. Pozostałe dwa pytania były pytaniami otwartymi.

Tematykę pytań przypisano do trzech szczegółowych problemów badawczych sformułowanych w postaci następująco:

- Czy własna wiedza, umiejętności i zdolności wpływają na przedsiębiorczość uczniowską?

- Czy otoczenie (rodzina, szkoła, miejsce zamieszkania) sprzyja kreowaniu postaw przedsiębiorczych?

- Czy narodowość determinuje intencje przedsiębiorcze uczniów?

Problemy szczegółowe zagregowano do problemu głównego wyrażonego w pytaniu:

- Jakie są intencje przedsiębiorcze młodzieży licealnej uczącej się w międzynarodowej grupie rówieśniczej, determinowane polskimi realiami (polską państwowością)?

Do ograniczeń badawczych należy zaliczyć brak odpowiedzi w niektórych kwestionariuszach, co powodowało zróżnicowanie liczebności końcowej w poszczególnych kategoriach. Kontrolnie przebadano grupę, która w przekroju odpowiedzi dostarczyła komplet danych. Porównanie wyników kontrolnych z docelowymi nie wykazało znaczących odchyleń, w związku z czym za 100\% przyjęto każdorazowo liczebność danej kategorii. Mimo że w przypadku Szczecin International School przebadano wszystkich uczniów, to należy uznać, że badania miały charakter pilotażowy, a na ich podstawie nie powinno się wyciągać daleko idących uogólnień. Autorom przyświecał jednak cel sprawdzenia poprawności zdefiniowanych założeń.

Po realizacji badań terenowych zgromadzone dane pierwotne poddano obróbce. W tym celu stworzono macierz danych wejściowych, które poddano kodowaniu, a następnie przetworzeniu za pomocą arkusza kalkulacyjnego Microsoft Excel. Na podstawie uzyskanych wyników dokonano agregacji problemu oraz sformułowano wnioski. 
Wyniki badań

Z przeprowadzonych badań wynika, że większość uczniów deklaruje odpowiednio wysoką wiedzę, umiejętności i zdolności, aby podjąć dorywcze prace zarobkowe (rycina 1). Świadczy to o wysokiej samoocenie respondentów, niezależnie od badanej szkoły i grupy, zarówno polskiej, jak i zagranicznej. Uczniowie SIS deklarowali posiadanie szeregu twardych kompetencji, takich jak umiejętność produkowania materiałów filmowych, wykonywania prac pielęgnacyjnych z zakresu ogrodnictwa oraz umiejętności ratownika wodnego. Natomiast w ani jednym przypadku nie wskazali jako atutu przy podejmowaniu dodatkowej aktywności zarobkowej umiejętności posługiwania się językiem obcym. Z ich punktu widzenia wydaje się to oczywiste, natomiast z punktu widzenia drugiej badanej grupy już takie nie jest. Co interesujące, uczniowie ZSB deklarowali posiadanie nie tylko kompetencji twardych, często związanych z przyszłym zawodem, ale również predyspozycji psychofizycznych i umiejętności społecznych, takich jak pracowitość oraz umiejętność komunikacji interpersonalnej.

Wysoka samoocena respondentów słabo korelowała ze świadomością zastosowania wiedzy w praktyce. Uczniowie nie byli w pełni przekonani o niezbędności jej posiadania przed podjęciem pracy. Warto jednak zaznaczyć, że w odpowiedziach uczniów SIS dało się zauważyć wyraźne wskazanie na konieczność posiadania wiedzy i umiejętności

Rycina 1. Struktura odpowiedzi na pytanie: Czy masz odpowiednią wiedzę, umiejętności i zdolności, aby podjąć płatne prace dorywcze?

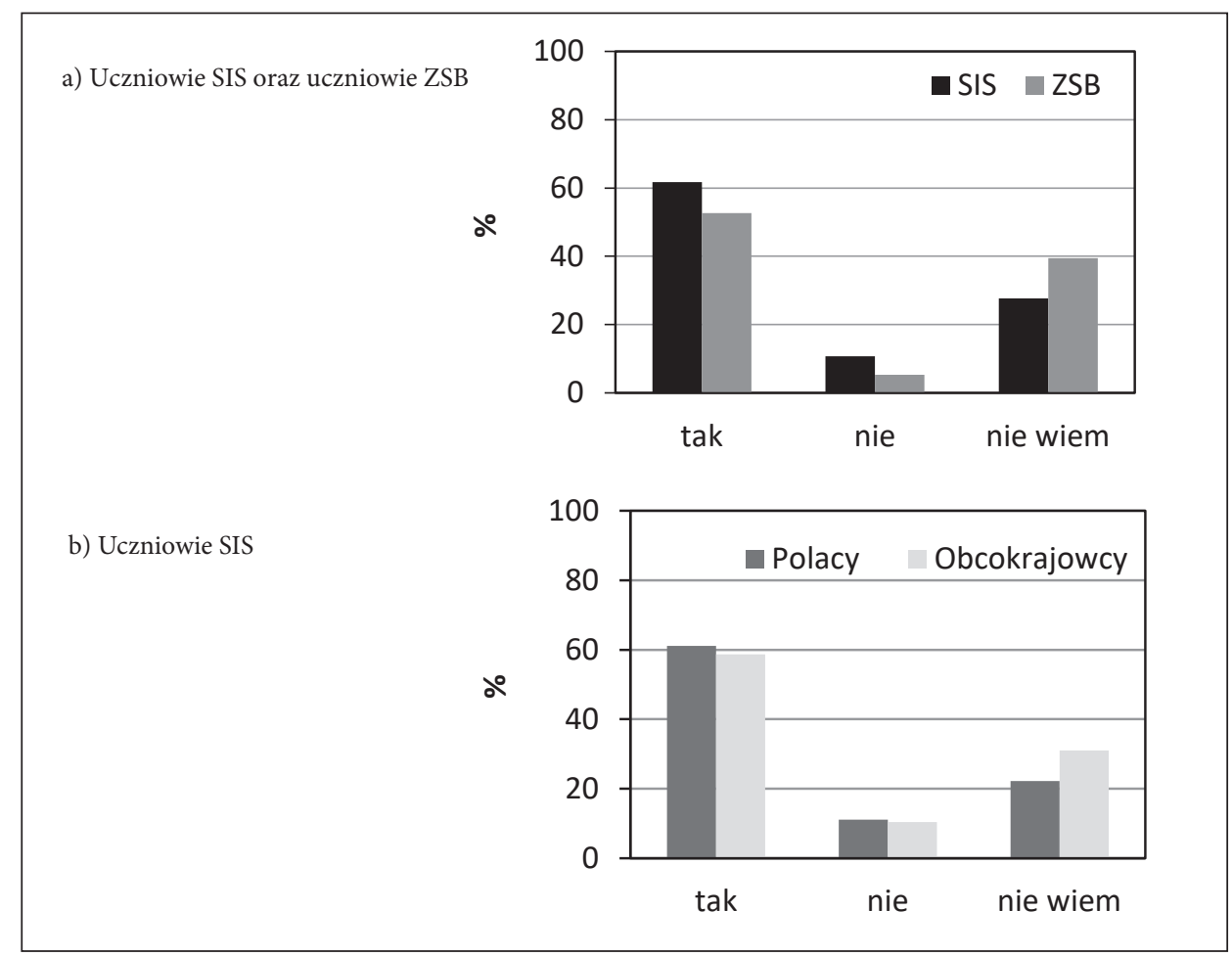

Źródło: opracowanie własne 
podstawowych, np. umiejętności czytania, liczenia itp., na wiedzę kierunkową, która nie zawsze może być potrzebna, oraz na wiedzę, ewentualnie - umiejętności, związane z konkretnym proponowanym stanowiskiem pracy, których posiadanie jest dla nich warunkiem sine qua non. Zgoła odmiennie na to pytanie odpowiedzieli uczniowie z ZSB. Otóż niemal jednogłośnie zanegowali oni konieczność posiadania zwłaszcza wiedzy, gdyż ta „przekazywana jest każdorazowo w nowym miejscu pracy, na nowym stanowisku pracy”. Taka postawa wydaje się jednak mało uświadomiona, ponieważ w życiu zawodowym przydaje się nam różnorodna wiedza. Czasem sytuacja wymaga wykorzystania wiedzy teoretycznej, a czasem musimy skorzystać z wiedzy praktycznej. Co więcej, czynimy to nieświadomie, odruchowo. Taka postawa jest również niepokojąca, ponieważ w prostej linii prowadzi do analfabetyzmu wtórnego i funkcjonalnego oraz redukcji sfery słowa, a w konsekwencji musi wpłynąć na relacje społeczne, także zawodowe.

Jak wynika z dalszych badań, obie badane grupy, tj. uczniowie ZSB i SIS, w tym obcokrajowcy, w ponad 70\% zgłaszają gotowość do podjęcia pracy zarobkowej. Różnice polegają na motywach takiej deklaracji, bowiem najczęściej występującym uzasadnieniem w odpowiedziach uczniów ZSB była chęć zdobycia środków na zaspokojenie własnych potrzeb oraz uniezależnienie się od rodziców, natomiast wśród uczniów SIS dominowało uzasadnienie o zdobyciu środków na dodatkowe wydatki (rycina 2). Podczas prowadzonych badań nie rozstrzygnięto jednak, co kryje się pod sformułowaniem „dodatkowe wydatki”. Wydaje się, że chodzi o dobra luksusowe, których cena nie pozwala na ich zakup z bieżących źródeł dochodów (np. kieszonkowe, stypendium). Co ciekawe, posiadanie takich dóbr okazało się prestiżowe i bardzo ważne dla uczniów pochodzących z innych krajów (79\%). Fakt ten być może wynika z młodzieńczej rywalizacji w ramach więzi rodzinnych i towarzyskich z rówieśnikami mieszkającymi w krajach pochodzenia. Wydaje się zatem, że gotowość do podjęcia pracy w przypadku polskich uczniów ma raczej podłoże ekonomiczne, a w przypadku obcokrajowców - podłoże społeczno-kulturowe.

Zarówno wysoki odsetek deklaracji o odpowiedniej wiedzy i umiejętnościach, jak i wysoki odsetek deklaracji o gotowości podjęcia pracy nie przekłada się na praktykę (rycina 3). Niemal 80\% obcokrajowców deklarujących chęć podjęcia pracy tej aktywności nie podejmuje. Może to wynikać z poziomu zamożności rodzin zagranicznych uczniów SIS, chociaż równie istotnym wydaje się nie tylko brak mobilizacji i presji ze strony rodziców i opiekunów, lecz także - czy przede wszystkim - ochrona przed prawdziwym wejściem na rynek pracy. Stąd większość podejmowanych działań zarobkowych przez młodzież cudzoziemską ogranicza się do prac przydomowych, raczej w obrębie rodziny i bliskich znajomych. Potwierdza to wcześniejszą tezę o społeczno-kulturowym podłożu intencji przedsiębiorczych obcokrajowców.

W przypadku polskich uczniów skala i szeroki wachlarz podejmowanych prac dorywczych są silnie zdeterminowane rodzajem szkoły (w tym być może zdobywaną, ukierunkowaną wiedzą i umiejętnościami), a także statusem społeczno-ekonomicznym rodziny ucznia. Można przyjąć, że szkoła profilowana ułatwia wejście na rynek pracy. Potwierdza to wyraźnie wyższy odsetek młodzieży podejmującej pracę obserwowany w grupie uczniów z ZSB (55\%) w stosunku do uczniów uczęszczających do SIS (34\%). Zastanawia fakt, że pracę podejmują również te osoby, które krytycznie oceniają swoje przygotowanie i dla których wiedza i umiejętności nie mają znaczenia. Oznacza to, że ze strony pracodawców nie ma presji na przygotowanie do wykonywania określonych czynności, co można tłumaczyć prostotą proponowanych stanowisk pracy lub relacją ucznia 
Rycina 2. Struktura odpowiedzi na pytanie: Czy chciałbyś już podjąć pracę?

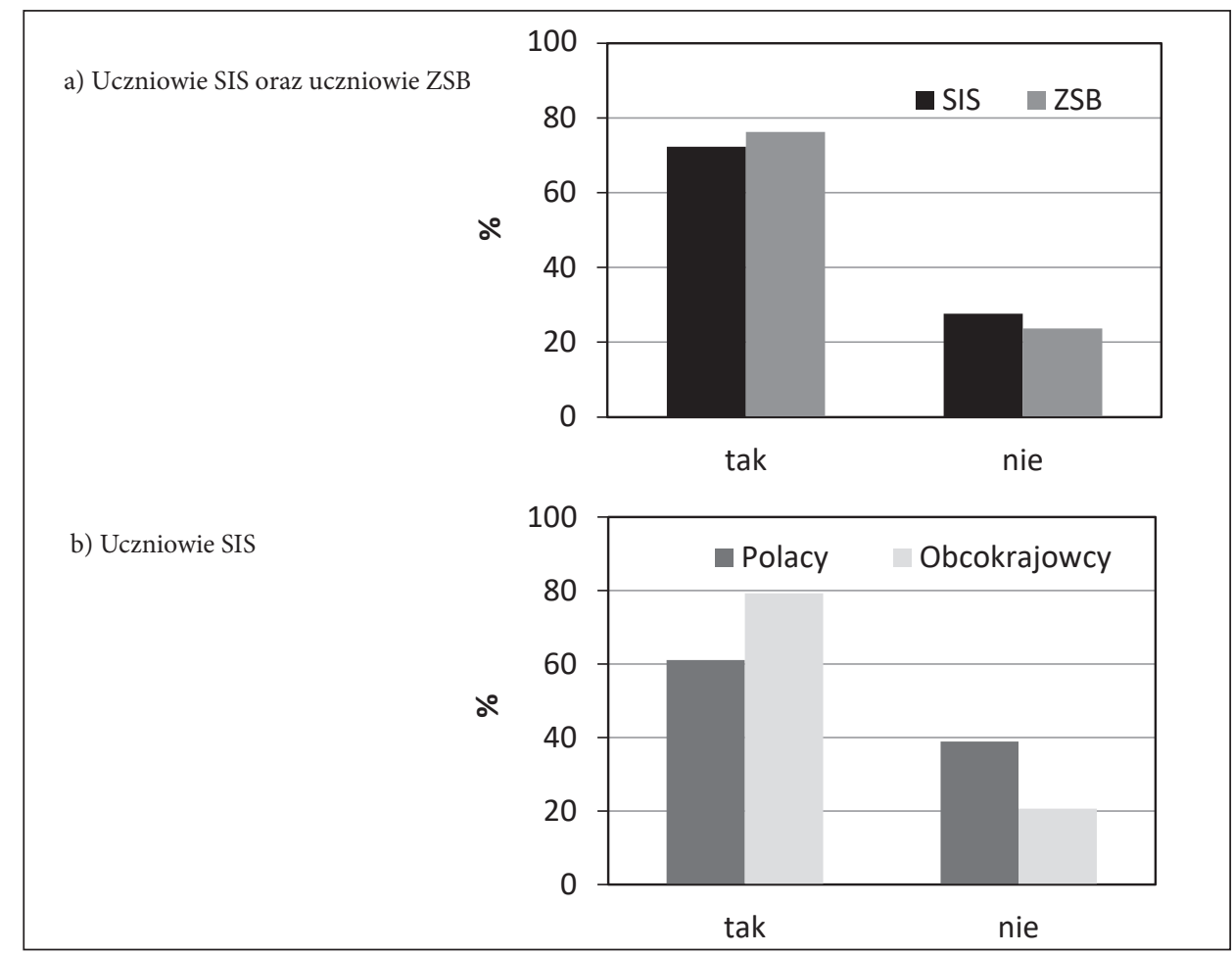

Źródło: opracowanie własne

z pracodawcą, często członkiem rodziny. Wyjaśniać to może również charakter wykonywanej pracy: sezonowy, biznes rodzinny czy wolontariat. Nade wszystko przyczyną takiego stanu rzeczy jest deficyt siły roboczej na rynku i gwałtowne obniżenie wymagań stawianych przez pracodawców potencjalnym pracownikom.

Silna determinacja do podjęcia pracy nie przekłada się również na pomysł na własny biznes. Za ciekawe należy uznać wyniki dotyczące miejsca i formy przyszłego zatrudnienia. W połowie badanych przypadków brakowało pomysłu na własną karierę zawodową. Pozostała część uczniów deklarowała chęć prowadzenia własnej działalności. Co ważne przeważnie za bliżej nieokreśloną granicą. Dotyczy to głównie uczniów zagranicznych, a w mniejszej skali uczniów polskich. Ich argumentacja o niewybieraniu Szczecina, czy szerzej - Polski jako miejsca działalności gospodarczej odnosi się głównie do czynnika finansowego, tj. możliwości uzyskania wyższych zarobków. W tym kontekście jako zagranicę należy rozumieć tylko kraje wysokorozwinięte. Istnieje jednak znaczna grupa uczniów (niezależnie od szkoły), która deklaruje podjęcie działalności gospodarczej w kraju. Deklaracje krajowe najprawdopodobniej wynikają z rodzinnych tradycji i dotyczą uczniów, którzy w przyszłości przejmą przedsiębiorstwo swoich bliskich.

Poza zasobem intelektualnym ucznia, będącym niewątpliwie bazą jego możliwości, na rozwój postaw przedsiębiorczych mogą oddziaływać dodatkowo rodzice, opiekunowie, szkoła, słowem - całe najbliższe środowisko, warunkowane pośrednio otoczeniem dalszym, czyli tytułową państwowością. Jak wynika z ustaleń autorów, respondenci 
Rycina 3. Struktura odpowiedzi na pytanie: Czy podejmujesz już płatne prace dorywcze?

a) Uczniowie SIS oraz uczniowie ZSB

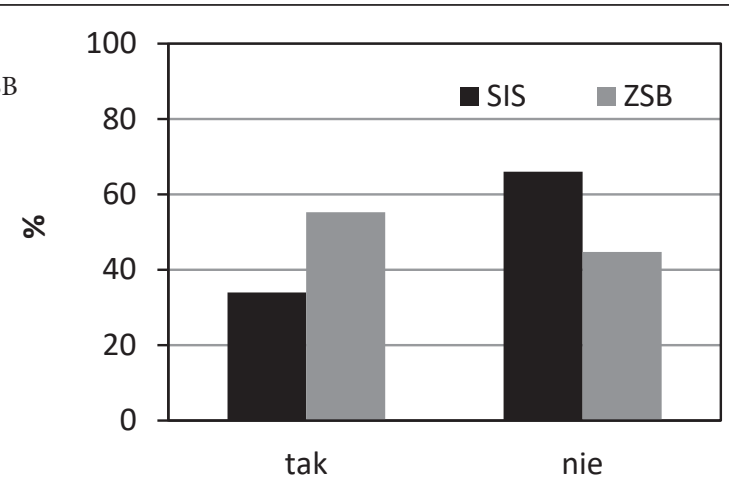

b) Uczniowie SIS

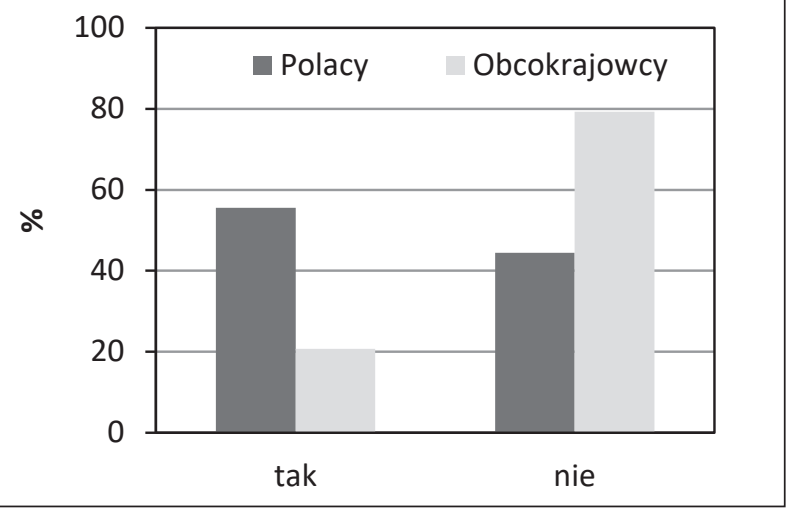

Źródło: opracowanie własne

zgłaszali wysoki poziom wsparcia w kreowaniu intencji i pierwszych działań przedsiębiorczych, zwłaszcza ze strony rodziny. Respondenci zapytani o wsparcie ze strony rodziny zdecydowanie je potwierdzili. Uczniowie SIS w ponad 72\%, uczniowie ZSB - w 79\% (rycina 4). Równie wysokie wartości otrzymano, dokonując podziału uczniów na Polaków i obcokrajowców. Wsparcie zadeklarowało wówczas 78\% uczniów polskich i 69\% uczniów zagranicznych.

Prawdopodobnie tak wysoki odsetek wsparcia wynika $z$ tradycji rodzinnych, według których dzieci kontynuują ścieżkę zawodową rodziców, lub z sytuacji materialnej, kiedy istnieje konieczność podejmowania przez dziecko dodatkowej pracy zarobkowej celem utrzymania siebie i wsparcia rodziny. Powodów braku wsparcia ze strony najbliższych może być kilka. Sami respondenci udzielali odpowiedzi, że „oni sami nie są zainteresowani podjęciem pracy”, „takie tematy nie pojawiają się w domu” lub pojawia się powielane wielokrotnie sformułowanie „skup się na nauce, na pracę przyjdzie jeszcze czas”. W przypadku uczniów szkoły SIS można mówić nie tyle o braku wsparcia rodziny, ile o braku zachęty ze strony rodziny do podejmowania aktywności przedsiębiorczych, co również ma związek z poziomem zamożności. W przypadku respondentów ze szkoły ZSB brak wsparcia może świadczyć o przypadkowości wyboru szkoły lub samej postawie uczniów niepokornych, poszukujących innego pomysłu na życie niż pomysły wskazywane przez najbliższą rodzinę. 
Rycina 4. Struktura odpowiedzi na pytanie: Czy rodzina wspiera twoje inicjatywy związane z podjęciem płatnych prac dorywczych?

a) Uczniowie SIS oraz uczniowie ZSB

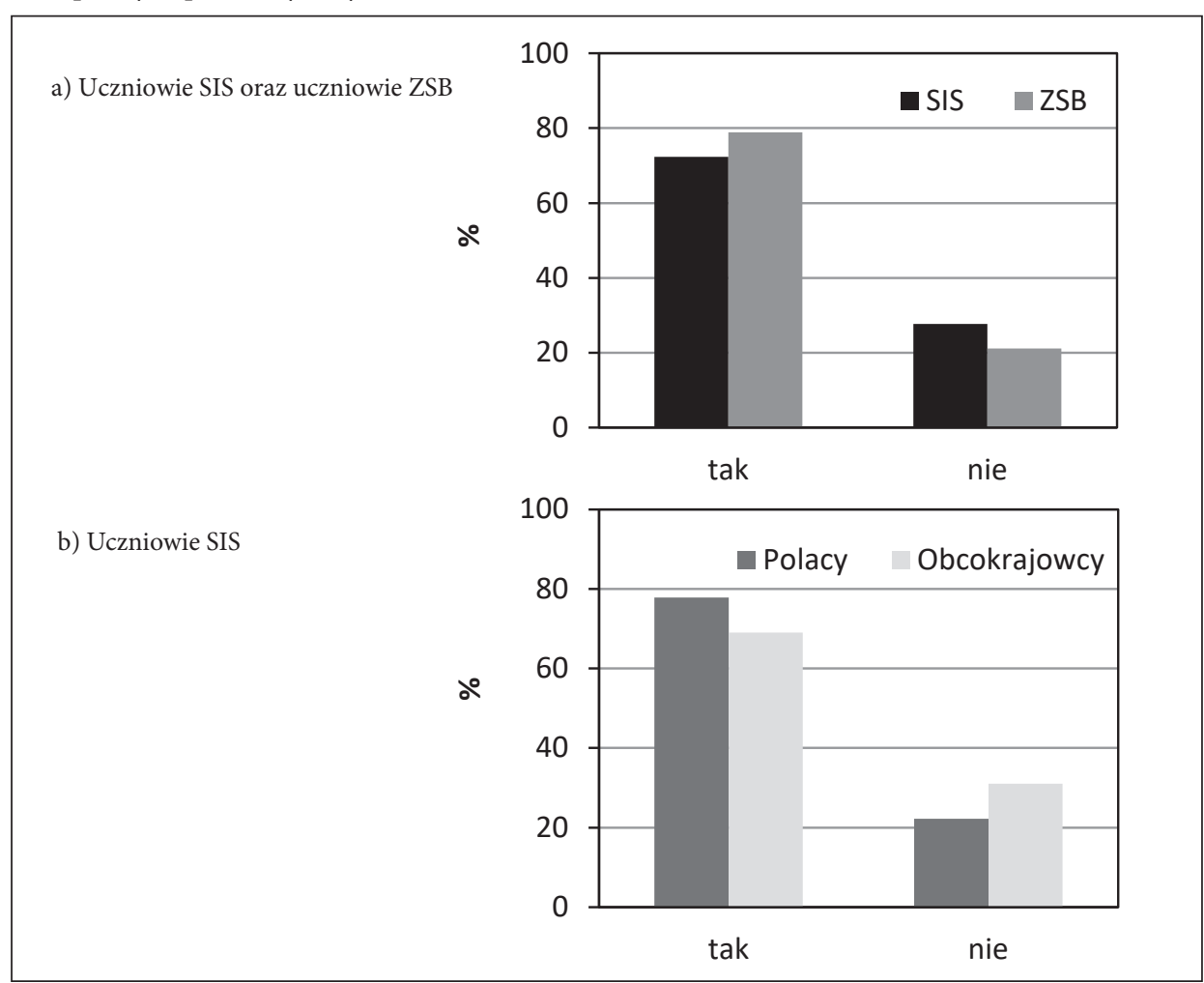

Źródło: opracowanie własne

W trakcie prowadzonych badań respondentom zadano pytanie: Czy istnieją w szkole zajęcia, na których rozmawiacie o rynku pracy i pomyśle na własny biznes? Uzyskane odpowiedzi wskazują na dwa skrajne stanowiska. W niepublicznej szkole SIS takich zajęć nie ma, a rozmowy, które odbywają uczniowie z nauczycielami, zależą jedynie od dobrej woli obu stron. Trudno zatem mówić o wsparciu szkoły w pierwszych działaniach przedsiębiorczych swoich uczniów. Natomiast uczniowie ZSB obligatoryjnie realizują zajęcia z podstaw przedsiębiorczości i doradztwa zawodowego oraz biorą udział w szeregu programów wspierających rozwój kompetencji organizowanych w murach szkoły.

Poza wsparciem ze strony rodziny i szkoły w badaniach zwrócono również uwagę na ewentualne bezpośrednie lub pośrednie wsparcie otoczenia, w naszym przypadku rozumiane jako miasto Szczecin. Z otrzymanych odpowiedzi wynika, że Szczecin może, ale nie musi być w przyszłości miejscem pracy dla większości badanych. W strukturze odpowiedzi na pytanie: Czy Szczecin jest miastem, w którym widzisz szansę na własny biznes? przeważa odpowiedź „nie wiem” (45\% uczniów SIS i 46\% uczniów ZSB). Uzyskany wynik należy tłumaczyć stosunkowo młodym wiekiem respondentów i relatywnie odległą perspektywą czasową właściwego wejścia na rynek pracy, przy dość specyficznym poczuciu upływu czasu. Jednocześnie daje się zauważyć wyraźna pasywność w określeniu wizji swojego miejsca na Ziemi i miejsca swojej przyszłej pracy zawodowej. Wydaje się, 
Rycina 5. Struktura odpowiedzi na pytanie: Czy narodowość ma znaczenie w przedsiębiorczości?

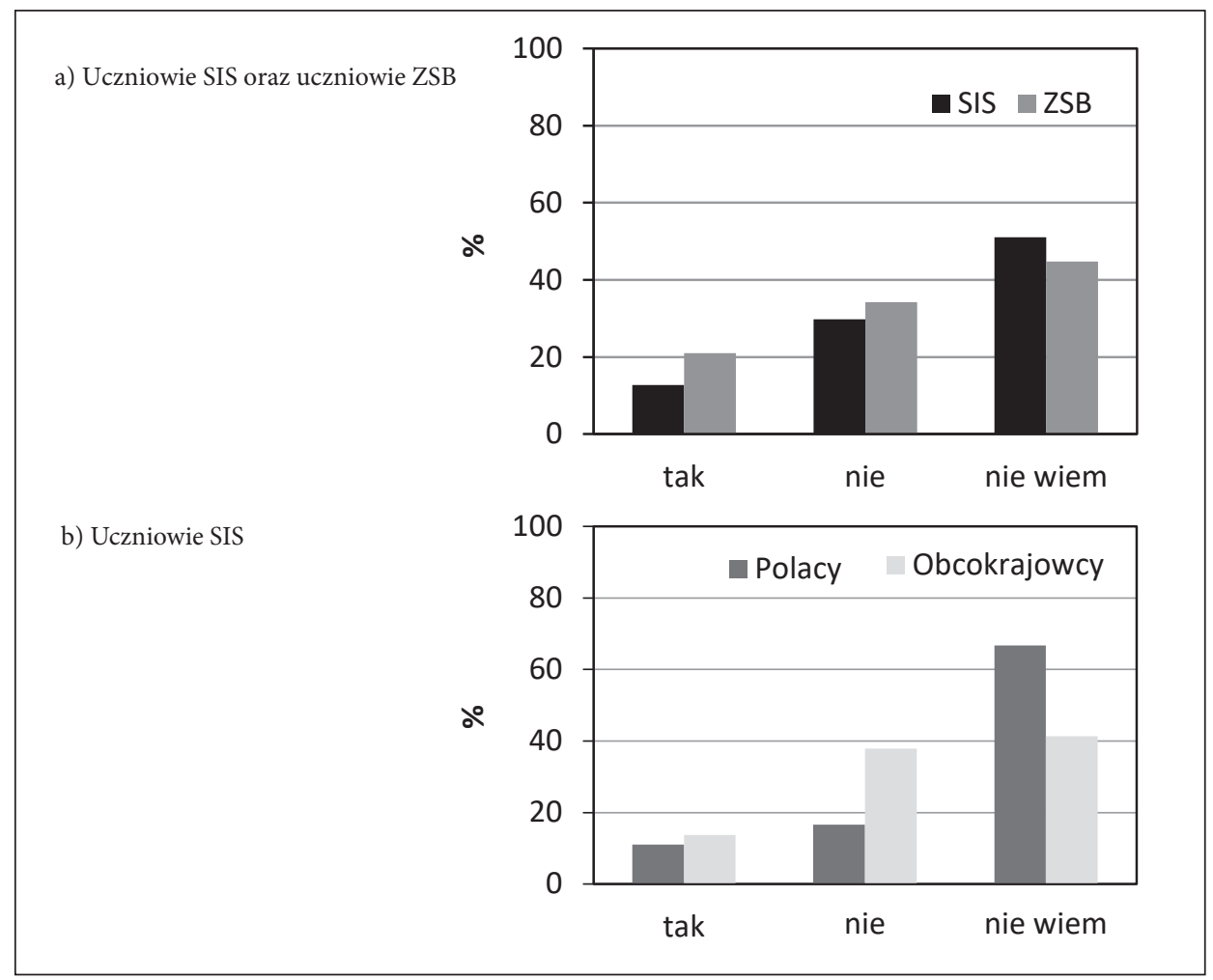

Źródło: opracowanie własne

że niechęć do ulokowania swojej działalności w Szczecinie wśród młodzieży ZSB wynika ze „zbyt dużej konkurencji w dużym mieście”, „nasycenia rynku pracy” wybranymi przez uczniów aktywnościami, a także konieczności poniesienia „zbyt dużych kosztów” na rozpoczęcie działalności. Równie źle warunki te oceniają obcokrajowcy ze szkoły SIS, którzy przeciwwskazań doszukują się w uwarunkowaniach społecznych, tj. „barierze językowej”, i uwarunkowaniach makroekonomicznych kraju, tj. „zbyt niskich wynagrodzeniach". Wydaje się zatem, że polska państwowość, tak uczniów zagranicznych, jak znaczną większość uczniów polskich, raczej zniechęca do podejmowania działań przedsiębiorczych, a specyficzne położenia Szczecina i jego charakter nie poprawiają tego stanu rzeczy. W perspektywie strategicznej taka sytuacja wydaje się bardzo niekorzystna, zwłaszcza z punktu widzenia potencjalnych miejskich liderów przedsiębiorczości.

Ostatnim analizowanym elementem badań była próba oceny wpływu narodowości na poziom przedsiębiorczości uczniów. Wyniki okazały się jednak bardzo trudne do interpretacji, ponieważ w otrzymanych odpowiedziach dominuje niezdecydowanie i wątpliwości ponad 51\% uczniów SIS i ok. 45\% uczniów ZSB (rycina 5).

Dla 38\% uczniów zagranicznych SIS narodowość nie ma znaczenia w podejmowaniu aktywności zarobkowej, a ich opinie potwierdzają wcześniejsze wypowiedzi na temat istotności wiedzy i umiejętności. Zastanawia przy tym ciągłe akcentowanie w tej grupie zdolności językowych. Być może wynika to z niskiej satysfakcji uczniów podczas 
codziennych, bezpośrednich kontaktów lub z przyjmowanej w domu, a jeszcze bardziej w szkole - doktryny.

Polscy uczniowie SIS wykazują się dużo większym niezdecydowaniem w ocenie wpływu narodowości na przedsiębiorczość aniżeli uczniowie zagraniczni. Otrzymane wartości to odpowiednio $76 \%$ dla uczniów polskich i zaledwie $41 \%$ dla uczniów zagranicznych. Ten wysoki odsetek niedecydowania polskich uczniów można łączyć ze znacznie bardziej ograniczonym terytorialnie doświadczeniem i kontaktami, co nie pozwala na zajęcie zdecydowanego stanowiska. Z dodatkowych obserwacji wynika również widoczna pasywność przy próbach uzasadnienia odpowiedzi na to pytanie i stąd ostatecznie wybór odpowiedzi „nie wiem” lub też podpatrywanie opinii u swoich kolegów i koleżanek z grupy zagranicznej. W szerszej refleksji zauważono, że pomimo dużej ilości czasu, jaki respondenci spędzają ze sobą w ciągu dnia, być może także poza zajęciami szkolnymi nie pojawiły się żadne pomysły na wspólne działania, a przynajmniej - intencje przedsiębiorcze. Niewystarczającym bodźcem okazały się także badania autorów. Podejmowane wspólne przedsięwzięcia uczniów dotyczą jedynie (zwykle obligatoryjnych) projektów szkolnych, natomiast nie są pogłębiane i przenoszone na grunt pozaszkolny.

W przypadku uczniów ZSB przyjęte $\mathrm{w}$ odpowiedziach stanowisko dotyczące znaczenia narodowości dla przedsiębiorczości jest bardziej konkretne, tzn. posiada większą liczbę zwolenników i przeciwników. Również w przypadku pytania dotyczącego cech narodowych, które miałyby sprzyjać przedsiębiorczości, odpowiedzi uczniów ZSB są bardziej kategoryczne, co więcej - nie pojawia się wśród nich odpowiedź „żadna”. Każdy z uczniów opowiedział się za istotną według niego cechą narodową, która sprzyja przedsiębiorczości. Wśród cech wybieranych najczęściej znalazły się: „zaradność” (34\%) „pracowitość” i „sumienność” (po 22\%) oraz „pewność siebie” (16\%). Jednoznaczny wybór uczniów może wynikać z informacji płynących bezpośrednio z otoczenia, ale również z podpatrywania dobrych praktyk, gdzie zaradność często rozumiana jest jako umiejętność reagowania w sytuacjach nietypowych, co rzeczywiście wyróżnia Polaków tak w kraju, jak i za granicą (m.in. Kotlarska-Michalska, Nosal, 2016; Zagórski i in., 2015). W tym kontekście zaskakują odpowiedzi uczniów SIS. W 44\% ogółu ankiet z tej szkoły na pytanie o cechę narodową („narodu, z którego się wywodzisz”), która sprzyja przedsiębiorczości pojawiła się odpowiedź „żadna”. Ponad 80\% tej grupy uczniów stanowili Polacy. W poszukiwaniu przyczyn tego stanu należy zwrócić uwagę na międzynarodową formę kształcenia tej szkoły, w której promuje się równorzędność kultur i ich wzajemne przenikanie, z czego mogą brać się trudności w identyfikacji własnych cech narodowych. Być może jest to również wynik frustracji młodych Polaków, którzy dokonują naturalnych porównań (np. w grupie rówieśniczej). Przyczyną może być również bierność uczniów wynikająca z uprawiania przez rodziców lub opiekunów filozofii „ciepłej wody w kranie”.

W odpowiedziach uczniów SIS (głównie zagranicznych), którzy wskazali jednak cechy narodowe sprzyjające przedsiębiorczości, na uwagę zasługuje „przyjazność” (45\% wskazań), jednak nie jest ona cechą indywidualną i raczej trudno ją utożsamiać z konkretnym narodem. Z komentarzy do tej odpowiedzi można wnioskować, że uczniom, głównie z Litwy i Danii, chodziło raczej o „otwartość”, pod którą kryje się nie tylko „przyjazność”, ale również „łatwość wyrażania opinii”. Obcokrajowcy z Niemiec i Estonii podkreślili też znaczenie takich cech, jak „punktualność”, „odwaga”, „wydajność”. 


\section{Zakończenie}

Przechodząc do wniosków szczegółowych wynikających bezpośrednio z przeprowadzonych badań, należy stwierdzić, że mimo kilku podobieństw istnieją różnice w postawach przedsiębiorczych uczniów z SIS i ZSB. Podział ten wynika przede wszystkim z charakteru i statusu szkoły oraz powiązanej z nią sytuacji społeczno-kulturowej i ekonomicznej rodzin uczniów. Pomiędzy badanymi szkołami istnieją duże różnice w pojmowaniu roli i znaczenia przedsiębiorczości dla młodego pokolenia tak na poziomie formalnym (brak zajęć przygotowujących uczniów do wejścia na rynek pracy), jak i mentalnym (pobudzanie intencji przedsiębiorczych, także na podstawie kontaktów i doświadczeń międzynarodowych), w obu przypadkach na korzyść technikum zawodowego w Zespole Szkół Budowlanych. Taki podział utrwala dodatkowo zróżnicowanie społeczne rodzin uczniów każdej ze szkół. Ponadto wydaje się, że rodziny uczniów Szczecin International School (SIS) - świadomie albo nie - odwlekają kreowanie postaw przedsiębiorczych wśród swoich dzieci i wychowanków, co może mieć w przyszłości bardzo negatywne konsekwencje. Natomiast przyczyn takiego postępowania należy szukać zarówno w poziomie zamożności, społeczno-kulturowej charakterystyce rodzinno-towarzyskiej jak i w mniej lub bardziej sprecyzowanych planach dotyczących przyszłości młodego pokolenia, w tym miejsca jego dalszej kariery szkolnej i zawodowej. Potwierdzają to pojedyncze intencje przedsiębiorcze, które mają bardziej przemyślany charakter.

Najistotniejszym podobieństwem w postawach respondentów jest duża ich determinacja do podjęcia działalności zarobkowej oraz to, że swojej aktywności nie łączą z zespołem działań przedsiębiorczych poprzedzonych świadomym planowaniem działań. Uczniowie deklarują raczej działania doraźne, czasem przypadkowe, nie zawsze lubiane itp. Wśród polskich i zagranicznych uczniów inna jest motywacja gotowości do podjęcia aktywności, ale przynajmniej na poziomie deklaracji zakłada ona działania z pominięciem intencji. W wielu opiniach i komentarzach uczniów zebranych podczas badań daje się wyczuć pasywność wobec przyszłego miejsca pracy. Dominuje niechęć do tworzenia własnych pomysłów na biznes, a duża część uczniów już deklaruje chęć wykonywania pracy najemnej.

Miasto Szczecin rozumiane jako otoczenie wpisujące się jednocześnie w szeroko pojętą państwowość, mimo swego charakteru (miasto portowe) oraz specyficznego położenia (jedyna w Polsce metropolia transgraniczna) nie wpływa mobilizująco na intencje przedsiębiorcze młodzieży. W przypadku wielu uczniów aktualne miejsce pobierania nauki nie wpłynie decydująco na wybór miejsca kariery zawodowej, a nawet miejsca dalszej edukacji szkolnej. Uczniowie nie dostrzegają szeroko pojętej wyjątkowości Szczecina jako miejsca prowadzenia działalności gospodarczej. Linia podziału przebiega po granicy państwowej i to na korzyść mniej lub lepiej sprecyzowanej zagranicy.

Powyższe uwagi potwierdzają postawioną we wstępie tezę, iż normy społeczne i kody kulturowe obowiązujące w danym kraju nie muszą determinować cech osobowościowych i sposobów myślenia ucznia, w tym obcokrajowca.

Reasumując, wyniki przeprowadzonych badań wskazują na konieczność dalszego ich prowadzenia nie tylko w wybranych szkołach, lecz także kompleksowo, ponieważ społeczności uczniowskie mogą znacznie różnić się od siebie. Interesujące byłoby również badanie młodzieży z większej liczby polskich miast, w których młodzież licealna uczy się w międzynarodowych grupach rówieśniczych, co mogłoby pomóc w lepszym zrozumieniu intencji i działań przedsiębiorczych obcokrajowców chcących podjąć aktywność gospodarczą w naszym kraju. 
Literatura

References

Ajzen, I. (1985). From intentions to actions: A theory of planned behavior. W: J. Kuhn, J. Beckman (red.), Action-control: From cognition to behavior. Heidelberg: Springer.

Ajzen, I. (1991). The theory of planned behavior. Organizational Behavior and Human Decision Processes, 50(2), 179-211.

Ambad, S.N.A., Damit D.H.D.A. (2016). Determinants of Entrepreneurial Intention among Undergraduate Students in Malaysia. Procedia Economics and Finance, 37, 108, 114.

Chaber, P., Łapiński, J., Nieć, M., Orłowska, J., Zakrzewski, R., Widła-Domaradzki, Ł., Domaradzka, A. (2018). Raport o stanie sektora matych i średnich przedsiębiorstw w Polsce. Warszawa: Polska Agencja Rozwoju Przedsiębiorczości.

Czapliński, P., Kibych, I. (2017). Postawy abiturientów wobec rynku pracy. Szczecin i Czerniowce - studium przypadku. Przedsiębiorczość - Edukacja, 13, 405-415.

Czapliński, P., Vepryk, N. (2008). Postawy młodzieży Polski i Ukrainy wobec rynku pracy. Dokumentacja Geograficzna, 36, 165-170.

Doroszewski, W. (1996). Słownik poprawnej polszczyzny. Warszawa: PWN.

Fayolle, A., Liñán, F. (2014). The future of research on entrepreneurial intentions. Journal of Business Research, 67, 663-666.

Fishbein, M., Ajzen, I. (1975). Belief, attitude, intention, and behavior: An introduction to theory and Research. Reading: Addison-Wesley.

Fishbein, M., Ajzen, I. (2010). Predicting and changing behavior: the reasoned action approach. New York: Psychology Press.

Global Entrepreneurship Monitor. (2018). Global Report. London: Global Entrepreneurship Research Association.

Kotlarska-Michalska, A., Nosal, P. (2016). Zaradność społeczna. Współczesne przejawy i ograniczenia. Poznań: UAM.

Krueger, N.F.Jr., Reilly, M.D., Carsrud, A. L. (2000). Competing models of entrepreneurial intentions. Journal of Business Venturing, 15, 41-432.

Kurczewska, A. (2010). Problemy pomiaru intencji przedsiębiorczych. E-mentor, 4, 12-16.

Kurczewska, A. (2013). Przedsiębiorczość jako proces współoddzialywania sposobności i intencji przedsiębiorczych. Warszawa: PWE.

Okręglicka, M., Havierniková, K., Mynarzová, M., Lemańska-Majdzik, A. (2017). Entrepreneurial intention creation of students in Poland, Slovakia and Czechia. Polish Journal of Management Studies, 15(2), 162-172.

Pawlak, A. (2015). Wpływ rodziców-przedsiębiorców na występowanie intencji przedsiębiorczych u młodzieży szkół średnich w Polsce. Przedsiębiorczość i Zarządzanie, 7(3), 71-82.

Rachwał, T., Wach, K. (2016). Badanie intencji przedsiębiorczych młodego pokolenia: wyniki ankietyzacji wśród studentów kierunków nieekonomicznych. Przedsiębiorczość - Edukacja, 12, 405-415.

Schlaegel, Ch., Koenig, M. (2014). Determinants of Entrepreneurial Intent: A Meta-Analytic Test and Integration of Competing Models. Entrepreneurship Theory and Practice, 38(2), 291-332.

Thompson, E.R. (2009). Individual Entrepreneurial Intent: Construct Clarification and Development of an Internationally Reliable Metric. Entrepreneurship Theory and Practice, 33(3), 669-694.

Wach, K. (2015). Środowisko biznesu rodzinnego jako stymulanta intencji przedsiębiorczych młodzieży akademickiej. Przedsiębiorczość i Zarządzanie, 7(3), 25-40.

Zagórski, K., Koźmiński, A.K., Morawski, W., Piotrowska, K., Rae, G., Strumińska-Kutra, M. (2015). Postawy ekonomiczne w czasach niepewności. Ekonomiczna wyobraźnia Polaków 2012-2014. Warszawa: Scholar.

Zbierowski, P. (2014). Determinanty intencji przedsiębiorczej studentów - wyniki badań. Horyzonty Wychowania, 13, 51-63. 
Barbara Osóch, dr, jest wieloletnim pracownikiem Zakładu Geografii Społecznej i Organizacji Przestrzeni Instytutu Geografii Społeczno-Ekonomicznej i Gospodarki Przestrzennej Uniwersytetu Szczecińskiego. Na tamtejszym uniwersytecie otrzymała tytuł magistra geografii i doktora nauk o Ziemi w dyscyplinie geografia. Szerokie zainteresowania z zakresu geografii społecznej, socjologii, turystyki wodnej oraz architektury zostały przedstawione w licznych publikacjach naukowych. Głównym obszarem zainteresowań naukowych jest rozwój przestrzeni geograficznej na potrzeby turystyki wodnej, żeglarstwa rekreacyjnego i struktury społecznej uczestników różnych form aktywności turystycznej.

Barbara Osóch, $\mathrm{PhD}$, is a long-term employee of the Social Geography and Spatial Organization Unit of the Institute of Social and Economic Geography and Spatial Management University of Szczecin. She is a long-term employee of the Social Geography and Spatial Organization Unit of the Institute of Social and Economic Geography and Spatial Management University of Szczecin. At the University she has graduated from Geographic and received a PhD in Earth Sciences. Extensive interests in the field of social geography, sociology, water tourism and architecture have been presented in numerous publications. The main area of research interest is the development of geographical space for the purposes of water tourism, recreational sailing and social structure of participants in various forms of tourist activity.

ORCID: 0000-0002-8364-7904

\section{Adres/Address:}

Uniwersytet Szczeciński

Wydział Nauk o Ziemi

Instytut Geografii Społeczno-Ekonomicznej i Gospodarki Przestrzennej

ul. Mickiewicza 18

70-383 Szczecin

e-mail: barbara.osoch@usz.edu.pl

Paweł Czapliński, dr hab. nauk o Ziemi w dyscyplinie geografia, w specjalności geografia ekonomiczna. W latach 1996-2014 asystent, a następnie adiunkt Instytutu Geografii i Studiów Regionalnych AP w Słupsku. Od 2014 r. profesor nadzwyczajny na Wydziale Nauk o Ziemi Uniwersytetu Szczecińskiego. Członek rad redakcyjnych czasopism: „Prace Komisji Geografii Przemysłu Polskiego Towarzystwa Geograficznego”, „Przedsiębiorczość - Edukacja” oraz „Rocznik Naukowy Państwowego Uniwersytetu w Chersoniu - seria Geografia”. Autor ponad 70 publikacji i monografii z zakresu transformacji struktur przestrzennych przemysłu Polski północnej, funkcjonowania i perspektyw rozwoju przemysłu przetwórstwa rybnego w Polsce, przedsiębiorczości młodzieży i osób starszych oraz wybranych aspektów z zarządzania i administracji samorządowej.

Paweł Czapliński, Professor of Earth Sciences (economic geography). In 1996-2014 assistant and associate professor in the Institute of Geography and Regional Studies, Pomeranian Academy in Słupsk. Since 2014 associate professor in the Faculty of Geosciences, University of Szczecin. Member of the editorial board of journals: Studies of the Industrial Geography Commission of the Polish Geographical Society, Entrepreneurship - Education and Scientific Journal of the Kherson State University - Geography. Author of more than seventy publications and monographs with subjects of transformation of spatial structures of industry in Northern Poland, performance and prospects of the development of the fish processing industry in Poland, entrepreneurship of young people and the elderly and some aspects of the management and administration of local government.

ORCID: 0000-0001-5093-941X

\section{Adres/Address:}

Uniwersytet Szczeciński

Wydział Nauk o Ziemi

Instytut Geografii Społeczno-Ekonomicznej i Gospodarki Przestrzennej

ul. Mickiewicza 18

70-383 Szczecin

e-mail: pawel.czaplinski@usz.edu.pl 